\title{
A newcomer from the east: naturalisation of Gypsophila perfoliata L. around the city of Miskolc (North-east Hungary)
}

\author{
András Schmotzer ${ }^{1}$, Attila Takács ${ }^{2} \&$ János Koscsó ${ }^{3}$ \\ ${ }^{1}$ Bükk National Park Directorate, Sánc u. 6, H-3304 Eger, Hungary, e-mail: schmotzera@bnpi.hu \\ 2 Department of Botany, Faculty of Sciences \& Technology, University of Debrecen, Egyetem tér 1, H- \\ 4032, Debrecen, Hungary \\ ${ }^{3}$ Sályi István u. 16, H-3529 Miskolc, Hungary
}

Schmotzer A., Takács A. \& Koscsó J. (2021): A newcomer from the east: naturalisation of Gypsophila perfoliata L. around the city of Miskolc (Northeast Hungary). - Thaiszia - J. Bot. 31 (2): 171-194.

Abstract: Gypsophila perfoliata (Caryophyllaceae) is a rare, only casually occurring species in Central Europe. Its native range spans from western Asian to the coast of the Black Sea. Several adventive occurrences of $G$. perfoliata were documented in Central Europe, especially in Germany where the naturalisation of the taxon occurred during the first decades of the 20th century. As a rare weed, it is suspected to have been introduced with iron ore from the former Soviet Union via railways (Kryvyi Rih region, now Ukraine). In this paper, we gathered information on the occurrence of $G$. perfoliata from its adventive range. These data indicate an ongoing and fast spread of the species across Central and Eastern Europe. For instance, prior to this study, G. perfoliata have two occurrence records from Hungary. Six new and recent records from Miskolc town and its surrounding areas are presented in this paper. The studied plant occurs in former industrial areas (steel factory, transshipment yards, external slag heaps) or along transport lines (esp. road verges, railway lines). We also describe 18 phytosociological relevés taken at the location of occurrences. All occurrences were documented on heavily modified anthroposols, where the populations flourish on bare ground (esp. road verges or parking areas) or on ground with admixture of metalliferous slag debris. With the help of available orthophotos the presumed land-use history of the locations has also been reconstructed. Based on data presented here we recommend modifying the species' adventive status in Hungary from casual to naturalised. Further expansion of the species is expected not only 
at industrial sites but also at locations where slag material was utilised (e.g. landfill, road and rail construction). Due to its halophyte characteristics the species might expand its range along roads where de-icing salt is used.

Keywords: Eastern migration route, distribution, new floristic records, slag heap, roadsides, Hungary, Gypsophila perfoliata.

\section{Introduction}

The percentage of the alien plants in the Central-European flora is rather high (exceeding over $10-20 \%$ of the entire flora in some countries). The suitability of disturbed, man-made habitats for the colonization and spread of non-native species in this region has been known for a long time (Kornaś 1990; Medvecká et al. 2012). Moreover, the process of urbanization and the accelerated transport of goods and materials across the continent are regarded as key drivers of plant invasions. Beside newcomers from the New World, the aliens originating from Asia form the predominant group of invasive plants in Europe (Pyšek et al. 2009). Most Asian aliens derive from the Far East (e.g., Fallopia spp., Echinocystis lobata, Humulus scandens), and much fewer examples of colonisation are known of continental Euro-Asian species that naturalised in Central Europe. Vladimír Jehlík has identified an Eastern plant migration route that has left a clearly detectable footprint on flora of the former Czechoslovakia, along which a significant increase in the number of the alien species could be observed (Jehlík 1998; Jehlík \& Dostálek 2008; Jehlík et al. 2017). Numerous Euro-Asian species present in Central Europe - mostly weeds with grain and wool - can be traced back to the former Soviet Union and were mostly introduced via ferroviatic transport. Gypsophila perfoliata L. is regarded as a schoolbook example of species introduced to Central Europe with iron ore, through this eastern gateway. Recently, this species was observed by the authors at six localities, where its occurrence was not documented previously, in and around the city of Miskolc (NE Hungary). The objectives of this study were to (i) present the current distribution of the species in Hungary, (ii) characterize the habitats of the newly discovered populations and (iii) add general remarks for its potential spread as an alien species.

The Gypsophila L. genus is a member of the pink family (Caryophyllaceae), containing nearly 150 species and representing the fourth largest genus of the subfamily Caryophylloideae Rabeler \& Bittrich (Bittrich 1993; Mabberley 2008). The region where the genus is present with the highest species diversity, also including several endemic species is located in the ponto-turano region, including the Black Sea region, the Caucasus, north Iraq and Iran (Barkoudah 1962).

The native range of Gypsophila perfoliata L. (section Paniculaeformes; known main synonyms: G. anatolica Boiss. \& Heldr., G. hygrophila Post, G. trichotoma Wender.) is 
Tab. 1 Summary of adventive occurrences of Gypsophila perfoliata from European countries based on original floristic papers.

\begin{tabular}{|c|c|c|}
\hline $\begin{array}{l}\text { Country / Region } \\
\text { (Location) }\end{array}$ & Habitat / comment & Reference \\
\hline $\begin{array}{l}\text { Russia / W-Siberia: } \\
\text { Khanty-Mansi } \\
\text { Autonomous Area } \\
\text { (Kuminskiy) }\end{array}$ & naturalised along railway embankment & $\begin{array}{l}\text { Glazunov et al. } \\
\text { (2016) }\end{array}$ \\
\hline $\begin{array}{l}\text { Russia / Moscow Region } \\
\text { (Moscow) }\end{array}$ & $\begin{array}{l}\text { rare casual species along the Moscow railway } \\
\text { to the direction of Kursk }\end{array}$ & $\begin{array}{l}\text { Bochkin \& } \\
\text { Vinogradova (2016), } \\
\text { Vinogradova et al. } \\
\text { (2017) }\end{array}$ \\
\hline $\begin{array}{l}\text { Russia / Vladimir Region } \\
\text { (Gus-Khrustalny, Tasino, } \\
\text { Molodniki) }\end{array}$ & $\begin{array}{l}\text { at a peat factory (in Gus-Khrustalny), the other } \\
\text { locations are along railway tracks, respectively }\end{array}$ & Seregin (2003) \\
\hline Russia / Penza Region & $\begin{array}{l}\text { naturalized species in disturbed areas with a } \\
\text { possibility to penetrate into semi-natural } \\
\text { habitats }\end{array}$ & $\begin{array}{l}\text { Vasjukov \& } \\
\text { Novikova (2017) }\end{array}$ \\
\hline $\begin{array}{l}\text { Russia / Middle Volga } \\
\text { Region, Volga Upland }\end{array}$ & $\begin{array}{l}\text { example of a plant species occupying } \\
\text { transformed habitats; naturalised species along } \\
\text { railways }\end{array}$ & $\begin{array}{l}\text { Pismarkina \& } \\
\text { Silaeva (2018), } \\
\text { Nikitin (2017) }\end{array}$ \\
\hline $\begin{array}{l}\text { Belarus (around Brest, } \\
\text { Mazyr, Vitebsk) }\end{array}$ & $\begin{array}{l}\text { as the discussed species Gypsophila paulii, it } \\
\text { grows mainly in anthropogenic habitats: on the } \\
\text { sides of roads, railways, wastelands, industrial } \\
\text { enterprises, coal and slag dumps (a distribution } \\
\text { map is presented) }\end{array}$ & Dzhus (2016) \\
\hline $\begin{array}{l}\text { Belarus / Homel Region } \\
\text { (Chojniki) }\end{array}$ & $\begin{array}{l}\text { on the slope of the railway embankments, a } \\
\text { rather large population was found on an area } \\
\text { of about } 500 \mathrm{~m}^{2}\end{array}$ & Tretiyakov (1988) \\
\hline Latvia (Daugavpils) & $\begin{array}{l}\text { Esplanade quarter of the town, as a weed } \\
\text { (detected first in 2010) }\end{array}$ & $\begin{array}{l}\text { Evarts-Bunders et } \\
\text { al. (2012) }\end{array}$ \\
\hline Ukraine / Poltava region & naturalised along railways & Dvirna (2017) \\
\hline $\begin{array}{l}\text { Ukraine / Dnipropetrovsk } \\
\text { Oblast (Kryvyi Rih) }\end{array}$ & $\begin{array}{l}\text { on iron ore dumps, in ruderal vegetation } \\
\text { according to slope and soil conditions }\end{array}$ & $\begin{array}{l}\text { Mazur et al. (2015), } \\
\text { Pavlenko et al. } \\
\text { (2017), Yeremenko } \\
\text { (2019) }\end{array}$ \\
\hline $\begin{array}{l}\text { Ukraine / Kiev City } \\
\text { Agglomeration (Kiev) }\end{array}$ & unintentionally introduced local casual species & $\begin{array}{l}\text { Mosyakin \& } \\
\text { Yavorska (2002) }\end{array}$ \\
\hline $\begin{array}{l}\text { Poland / Lesser Poland } \\
\text { Voivodeship (Stróża near } \\
\text { Myślenice) }\end{array}$ & $\begin{array}{l}\text { at the roadside by the modernized Kraków- } \\
\text { Zakopane dual carriageway, near the overpass } \\
\text { and the exit to the village center from } \\
\text { Myślenice (first record from the Polish } \\
\text { Carpathians) }\end{array}$ & $\begin{array}{l}\text { Bartoszek \& } \\
\text { Stachurska-Swakoń } \\
(2016)\end{array}$ \\
\hline $\begin{array}{l}\text { Poland / Lesser Poland } \\
\text { Voivodeship (Bodzanów } \\
\text { and } \\
\text { Łapczyca) }\end{array}$ & $\begin{array}{l}\text { on a roadside slope and in ditch in a pioneer } \\
\text { community with species from Stellarietea, } \\
\text { Artemisietea Epilobietea angustifolia and } \\
\text { Molinio-Arrhenatheretea classes (a national } \\
\text { distribution map is presented) }\end{array}$ & Pliszko (2016) \\
\hline $\begin{array}{l}\text { Poland / Lublin } \\
\text { Voivodeship (Zamość and } \\
\text { Hrubieszów) }\end{array}$ & $\begin{array}{l}\text { a disused side-track on the iron and sulphur } \\
\text { ore line (LHS) with a sandy-gravel surface } \\
\text { (Zamość) and reloading station of the LHS line, } \\
\text { between railway tracks (Hrubieszów) }\end{array}$ & $\begin{array}{l}\text { Święs \& Wrzesień } \\
\text { (2002) }\end{array}$ \\
\hline
\end{tabular}


Tab. 1 - cont.

\begin{tabular}{|c|c|c|}
\hline $\begin{array}{l}\text { Slovakia / Trebišov and } \\
\text { Michalovce District } \\
\text { (Čierna nad Tisou, Vel'ké } \\
\text { Kapušany) }\end{array}$ & at railway transshipment yards & $\begin{array}{l}\text { Jehlík et al. (2017), } \\
\text { Májeková et al. } \\
\text { (2020) }\end{array}$ \\
\hline $\begin{array}{l}\text { Czech Republic / } \\
\text { Moravian-Silesian Region } \\
\text { (Ostrava) }\end{array}$ & $\begin{array}{l}\text { it was collected on iron ore storage yards in } \\
\text { Ostrava-Vítkovice and Polanka nad Odrou, in } \\
\text { October } 1965 \text { by Zdeněk Kilián (national } \\
\text { distribution map is presented) }\end{array}$ & Kaplan et al. (2017) \\
\hline $\begin{array}{l}\text { Germany / foreland of } \\
\text { Harz Mts. }\end{array}$ & $\begin{array}{l}\text { secondary alkalic habitats at potash mining } \\
\text { areas (occurring at six locations from the } \\
\text { studied } 16 \text { potash areas) }\end{array}$ & Guder et al. (1998) \\
\hline $\begin{array}{l}\text { Germany / Thuringen } \\
\text { (Halle - Lochau) }\end{array}$ & $\begin{array}{l}\text { in a former brown coal mining area in } \\
\text { association with Kochietum densiflorae }\end{array}$ & $\begin{array}{l}\text { Gutte \& Klotz } \\
(1985)\end{array}$ \\
\hline $\begin{array}{l}\text { Germany / Lower Saxony } \\
\text { (around Hannover) }\end{array}$ & $\begin{array}{l}\text { in potash mining areas, at slag heaps with } \\
\text { other salt-tolerant species (joint distribution } \\
\text { map is presented with G. scorzonerifolia) }\end{array}$ & Garve $(1999 a, b)$ \\
\hline $\begin{array}{l}\text { Germany / Hessen } \\
\text { (Heimboldshausen) }\end{array}$ & at a salt dump & Mahn (1997) \\
\hline $\begin{array}{l}\text { Germany / Saxony-Anhalt } \\
\text { (Aken) }\end{array}$ & $\begin{array}{l}\text { on slag heap at a magnesite factory with } G \text {. } \\
\text { paniculata }\end{array}$ & Amarell (2002) \\
\hline $\begin{array}{l}\text { Bulgaria / Varna Province } \\
\text { (Razdelna) }\end{array}$ & $\begin{array}{l}\text { railway station at Razdelna (as G. trichotoma) } \\
\text { (the discussed species of the paper was } \\
\text { Grindelia squarrosa) }\end{array}$ & $\begin{array}{l}\text { Vladimirov \& } \\
\text { Petrova (2012) }\end{array}$ \\
\hline $\begin{array}{l}\text { Romania / Iași County } \\
\text { (Socola-laşi) }\end{array}$ & $\begin{array}{l}\text { along railway tracks at Socola-laşi railway } \\
\text { station, vegetation is belonging to Dauco- } \\
\text { Melilotion alliance (the target species of the } \\
\text { papers were Sisymbrium volgense and } \\
\text { Euphorbia davidii) }\end{array}$ & $\begin{array}{l}\text { Oprea \& Sîrbu } \\
\text { (2010), Oprea et al. } \\
(2012)\end{array}$ \\
\hline Moldavia / Chișinău & $\begin{array}{l}\text { subspontaneous occurrence with two } \\
\text { vegetative individuals at a sandy surface close } \\
\text { to a lake in public park „La izvor" }\end{array}$ & Pînzaru et al. (2018) \\
\hline $\begin{array}{l}\text { Moldova / Gagauz } \\
\text { Autonomous Territorial } \\
\text { Unit (Bugeac) }\end{array}$ & at Komrat railway station & Molnár et al. (2019) \\
\hline
\end{tabular}

concentrated in the steppe zone along the Black Sea region, but it occurs in north Mongolia and China, western Siberia (Verhojansk - Tobolsk region), the Aral - Caspi region, the Caucasus, the lower Don and Volga Basin and the Crimea (Shishkin 1936; Sommerwerk et al. 2005; Eliáš \& Dítě 2012). The westernmost native occurrences of the species are known from South Eastern Europe, Dobrogea region, in Bulgaria (Valev 1966; Petrova 2011; Valcheva et al. 2020) and in Romania respectively (Făgăraş et al. 2010; Ciocârlan 2011; Doroftei et al. 2011). The distribution map of its native range is presented by Rauschert (1977) and Jalas \& Suominen (1986). The adventive range of the species extends far westwards, reaching into Germany, where the species is well-known from several industrial areas (especially around potash salt or brown coal mining areas) in several federal states (Thüringen, Lower Saxony, Saxony-Anhalt, Hessen, Brandenburg; Garve \& Garve 2000; Jäger \& Werner 2005; Sommerwerk et al. 2005; Buttler \& Hand 2008). In the eastern part of Europe, the 
occurrences of G. perfoliata is well-documented in Poland (Bartoszek \& StachurskaSwakoń 2016), Slovakia (Jehlík 1998; Eliáš \& Dítě 2012) and Belarus (Tretiyakov 1988; Dzhus 2016). Historical casual occurrences of the species from the Czech Republic were confirmed only recently (Kaplan et al. 2017). It is also noteworthy, that even in countries where the species is considered native (e.g. Russia, Ukraine, Romania, Bulgaria and Moldova), adventive occurrences are also known. The native status of the species in Moldova is questionable, especially because it occurs in non-typical habitats of the species. G. perfoliata is listed as an alien in the flora of Italy (Galasso et al. 2018) and - as an introduced cereal weed - in Lebanon (Williams et al. 2015). It has also naturalised in the United States (reported from New England (Angelo \& Boufford 2011) and from Illinois states (Mohlenbrock \& Ladd 1978)), but most reports concerning this species appear to have been based on misidentified of $G$. scorzonerifolia (Barkworth et al. 1993). Tab. 1. gives a non-comprehensive summary of the species' adventive range with remarks on habitat preferences from eleven central and eastern European countries. Overall, it appears that defining the distribution range of $G$. perfoliata is problematic, mostly due to taxonomic uncertainties. Several taxa are now listed under G. perfoliata (mostly as synonyms), which were earlier regarded as a distinct species (e.g. G. trichotoma, G. paulii, G. tekirae). The European distribution map in EURO+MED database (Marhold 2011+) is also inaccurate: for instance, the indication of native occurrence of $G$. perfoliata in Spain is evidence for false information. The latter data most likely indicates the morphologically similar G. tomentosa L. (as 'G. perfoliata auct. hisp.') which does not occur in Central Europe (Schnedler 1977; López González 1990). Seed micromorphology and pollen morphology were also tested for systematic significance within the Gypsophila genus and related genera (Ataşlar et al. 2009; Amini et al. 2011). Economic importance and traditional use (e.g. as an ornamental plant) of the genus members is also relevant, especially within its native range (Balabanova et al. 2009; Korkmaz \& Özçelik 2011; Minarchenko 2017). Extraction from the roots of Gypsophila taxa contains 15 to $20 \%$ saponin glycoside and contain gypsogenine which is a pentacyclic triterpenoid and sugars such as galactose, ksilose, arabinose, fructose and rhamnose. At the south-western part of its natural range, G. perfoliata is a protected species and/or it is listed as 'threatened' on the red list of Bulgaria (Petrova \& Vladimirov 2009; Petrova 2011), Romania (Dihoru \& Negrean 2009) and Moldova (Ghendov et al. 2012). The species is considered to be 'near threatened' taxa according to the IUCN category in the EU27 and Europe as a whole (Allen et al. 2014).

The alien status of Gypsophila taxa in Hungary was clarified by Lajos Somlyay (2009), who revised available herbarium materials. He also created the first dichotomous identification key of the alien taxa of the genus occurring in Hungary. Based on the historical data, G. perfoliata is a rare, casually occurring species in Hungary (Balogh et al. 2004; Somlyay 2009; Király 2009). Before the 1990's a single confirmed location of the species was known: Sándor Polgár repeatedly collected it between 1919 and 1936 from the yard of the Meller's Oil Factory in Győr (Polgár 
1926, 1941; Schmidt 2016). The latter occurrence is well-documented by several herbaria specimens (see Somlyay 2009, Nótári et al. 2017). Floras after the Second World War considered G. perfoliata as an extinct species or whose presence can be doubted (e.g. Priszter 1985), some even omitting the species from national identification keys and enumerations (Simon 2000). A new single location of the species was published from Gesztely municipality (Borsod-Abaúj-Zemplén county) (Molnár 2014). The description of the locality was mentioned precisely ('Gesztely: at the beginning of the road that leads to Újharangod, to the south from the road, on a rubble heap'). The population size and the habitat and/or accompanying species were not mentioned in the paper.

\section{Material and Methods}

Within the framework of the current study, we carried out a field survey between 2011 and 2020 in and around Miskolc city, focusing on ruderal sites and anthropogenic habitats. The administration units, local toponyms and elevation data were elaborated with the help of 1:10 000 scaled national EOTR topographic maps, while municipality street names were derived from the Google Maps homepage (https://www.google.hu/maps). The names of landscape units follow the work of Dövényi (2010). Geo-coordinates of the localities were determined using Trimble Juno 3B and Spectra MobileMapper GPS devices. The GIS elaboration - incl. the editing of the distribution maps of the species - were carried out in ArcGIS 10.1 software environment. The Central European flora-mapping grid numbers (CEU) were also added with codes taken from the Central European Flora-mapping project (Niklfeld 1971; Király 2003). The phytosociological relevés were taken following the methods of the Zürich-Montpellier school. The size of the relevés varies between 0.25 and 16 square meter according to the population size and pattern. Percentage cover (\%) was estimated on the field, but later it was converted to graded abundance - dominance scale (Tremp 2005). Nomenclature of plants follows the work of Király (2009). In Tab. 2. the species were ordered according to phytosociological groups according to Oberdorfer (2001). With the help of available historic maps and orthophotos the presumed land-use history of the sites has also been reconstructed (e.g. archive orthophoto datasets of Lechner Nonprofit Ltd., https://www.fentrol.hu/hu). Voucher specimens were deposited in the Herbarium Carpato-Pannonicum collection of the Hungarian Natural History Museum Budapest (BP), herbarium of Debrecen University (DE), and Eszterházy Károly University, Eger (EGR). A successful seed-sowing was carried out at the Botanical Garden of the Eszterházy Károly University, where the study plant has been involved in cultivation. The observers' and collectors' abbreviations are the following: János Koscsó (JK), András Schmotzer (AS), Attila Takács (AT).

\section{The study species}

The main morphological features of Gypsophila perfoliata are the following according to Schedler (1977), Dequan \& Turland (2001) and Somlyay (2009): 
perennial herbs, yellow green, up to $70 \mathrm{~cm}$ tall. Stems erect, distally many branched, proximally glandular pubescent especially in the lower part of the stem (rarely the whole plant is glabrous). Leaves obovate- or ovate-oblong, 3-7 × 1-3 cm, glandular pubescent, 3-5-veined, base amplexicaul and slightly connate. Pedicel slender, 4-15 $\mathrm{mm}$, glabrous, more than twice as long as calyx. Calyx green veined, broadly campanulate, 2-3 mm, lobed for ca half of its length; lobes ovate, margin membranous, apex obtuse. Inflorescence is lax. Petals red, pink, or white, oblong, ca $5 \times 2 \mathrm{~mm}$, apex retuse or obtuse. Stamens slightly shorter than petals. Ovary ovoid. Capsule globose, longer than calyx. The brownish black reniform seeds are ca $1 \mathrm{~mm}$, minutely flat tuberculate with fine rib-like grains. The main morphological differences from other similar Gypsophila species (G. scorzonerifolia, G. tomentosa) are presented by Schedler (1977), also adding the illustrations of them.

\section{The study area}

The field surveys were carried out in Miskolc town and its suburbs (capital of Borsod-Abaúj-Zemplén county, North-east Hungary). The town is situated in a transitional zone of different landscape units between the Bükk Mts. (belonging to the Inner North-western Carpathians macro-region) and the Sajó-Hernád Plain (belonging to the Great Hungarian Plain macro-region). The botanical survey conducted within the framework of this study focused on the latter landscape unit, where the urbanisation and landscape transformation were significant. The city of Miskolc lies at an altitude of $110-250$ meter above sea level and its climate is classified as warm temperate. This climate is transitional between the warmer ' $\mathrm{Cfb}$ ' and the cooler ' $\mathrm{Dfb}$ ' temperate zones according to the Köppen-Geiger climate classification. The annual average temperature is $9.3-9.9^{\circ} \mathrm{C}$ and the annual average precipitation is around 540-580 mm (Dövényi 2010). The potential natural vegetation of the Sajó-Hernád Plain consists of alluvial floodplain forests (riverine willow-poplar or oak-elm-ash woodlands) and forest-steppe woodlands (e.g. tartar maple steppe oak woods) in terraces, but the original vegetation was altered and destroyed in most areas (Király et al. 2008; Takács et al. 2013). With a population of over 155.000 inhabitants Miskolc is the fourth largest city in Hungary. It is regarded as an industrial city, and the largest boost to its economy was provided by the industrialization during the socialist era, when the Diósgyőr Steel Mills were renamed as Lenin Metallurgical Factories (Lenin Kohászati Múvek, hereafter referred to as LKM, 1953-1989), which consequently emerged as a symbol of the Hungarian heavy industry (Pál 2017). Human intervention is very intensive in the studied area, reaching a metahemerobic level of landscape transformation (the term is according to Jalas 1955), which is characterised by dense urbanised areas, artificial, vegetationfree surfaces (e.g. mines, slag heaps) and developed railway and road networks (Csorba 2018). 


\section{Results and Discussion}

\section{1) Detailed description of new localities of Gypsophila perfoliata in the study area}

The map of the new localities of G. perfoliata is presented on Fig. 1.

Location-1: Miskolc - Csorba-telep. At the shopping centre zone north to the main road No. 3. (Auchan and Decathlon supermarkets); coordinates: $48^{\circ} 06^{\prime} 28,03^{\prime \prime} \mathrm{N}$, 2050'03,54"E; alt. $113 \mathrm{~m}$ a.s.I.; CEU grid: 7891.3. Observation: 13.7.2018 (AS). Coenological data: relevé 1. (Tab. 2).

Around 50-60 individuals were found at the parking areas of the above-mentioned malls. The plants occur on mulched side-walks by the asphalt roads. In some cases, the species was naturalised even in cracks of the road or of the passenger pavements (Fig. 2/A.). The population occupies an area around 1.5 hectares. The plant cover of this heavily transformed habitat, which is very sparse, few species tolerate these trampled, warm conditions (e.g. Poa annua, Portulaca oleracea, Lepidium ruderale, Lactuca serriola, Cerastium vulgare, Tragus racemosus).

The latter locality near Miskolc is situated on the alluvium of the Sajó (Slaná) river, where a new shopping centre zone was built in 2008-2009. The development of the supermarkets accelerated local traffic, and road infrastructure also evolved. The site is remarkably close to the primary junction of the main road No. 3 (leading to Košice) and M30 highway (Miskolc bypass).

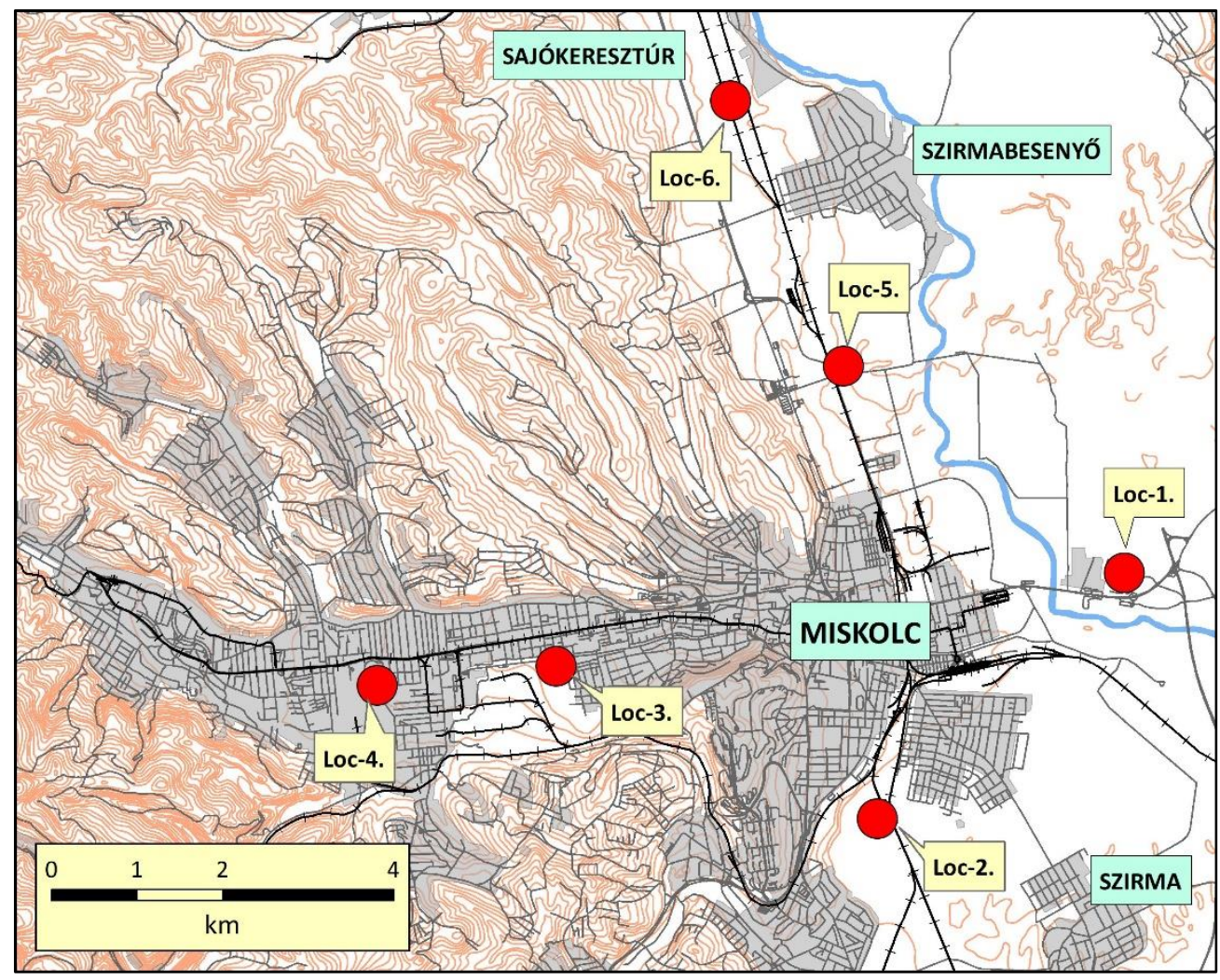

Fig. 1 Localization of the new occurrences of Gypsophila perfoliata in and around Miskolc. 
Location-2: Miskolc-Hejőcsaba: 'Gálos' slag heap of the former LKM, east from the inner town section of Main road No. 3. (Csabavezér út); centroid coordinates: $48^{\circ} 04^{\prime} 57,74^{\prime \prime} \mathrm{N}, 2^{\circ} 47^{\prime} 42,97 " \mathrm{E}$; alt. 130-150 m a.s.l.; CEU grid: 7990.2. Observation: 16.8.2011 (JK, AT), 26.7.2018 (AS, JK). Coenological data: relevé $2-11$ (Tab. 2).

A large population of $G$. perfoliata occurs on the metalliferous slag heap of the former LKM (Fig. 2/B-C). The overall population might exceed several hundred thousand individuals and it is most likely the biggest known population of the species in Central Europe. After the abandonment of the slag placement, secondary succession processes have started in the 1990's. The vegetation of the slag heap is very diverse at the moment, ranging from the nearly bare surfaces to closing black locust wood lots. This artificial surface of the heap covers over 250 hectares, and nearly $30 \%$ of the site is suitable for G. perfoliata. A small, ca 30 square metres stands of $G$. perfoliata was detected at 550 meters south-east from the main slag heap, next to the railway line linking Budapest and Miskolc (centroid coordinates: $48^{\circ} 04^{\prime} 34.6^{\prime \prime} \mathrm{N}$, $\left.20^{\circ} 48^{\prime} 05.9^{\prime \prime} \mathrm{E}\right)$. The plant grows on pioneer surfaces, where it forms dominant patches. Bare surfaces at the site are common, following the former excavations and modifications at the slag heap, but natural erosion processes (such as linear erosion, mass movement and slumping) were also important. The main accompanying species are annuals and ruderal forbs, such as Kochia scoparia, Conyza canadensis and Verbascum phlomoides. Some juvenile individuals of woody species are also present, such as Acer negundo, Ailanthus altissima, Betula pendula and Populus alba. Floristically interesting plants, such as Salsola kali, Microrrhinum minus and Tragus racemosus were recently documented from this location (Takács et al 2013).

The slag heap here was created in the 1960's when the factory yards of LKM at Diósgyőr reached the maximum capacity for slag waste deposition. New industrial railway lines were built and during a period of 30 years approximately 20-30-meterhigh deposit was created. The rationale behind selecting the site for slag deposition was also the presence of the cement plant nearby, at Hejöcsaba. The area was a natural depression with marshy reed vegetation (Phragmition australis and Calthion), which was partially filled up during the last decades. The location is one of the biggest environmentally hazardous sites in Hungary, because the soil and groundwater is heavily polluted with nickel, cadmium, chromium, lead and arsenic (Simon et al. 2017). The problem is not only derived from the metallurgical waste material (the untreated slag), but other non-hazardous waste can also be found, including concrete, cutting discs, insulation materials and tires. The local gardening maintenance company has used the area as a garden waste deposition area, this explains the naturalisation of some ornamental species (such as Robinia viscosa, Berberis spp., Chamaecyparis lawsoniana, Iris cf. germanica, Aster novae-angliae and Yucca filamentosa).

Location-3: Miskolc: Kiss Ernő street (at the Aldi and Lidl supermarkets), close to the canalised Szinva Brook; coordinates: 4805'57,13"N, 2044'47,44"E; alt. $145 \mathrm{~m}$ a.s.I.; CEU grid: 7990.1. Observation: 23.8.2019 (AS, JK). Coenological data: relevé 12-13. (Tab. 2). 
Over 12000 individuals were estimated at the accessible part of the supermarkets' parking area (Fig. 2/D). Here G. perfoliata forms massive homogenous patches on slag-rich degraded soil. The vegetation of the locality varies according to the soil's conditions. On trampled, bare grounds pioneer stands of annuals (e.g. Ambrosia artemisiifolia, Setaria pumila, Convolvulus arvensis, Conyza canadensis, Kochia scoparia, Tragus racemosus, Panicum capillare) are characteristic, while in closing stands perennial grasses and forbs become dominant (e.g. Elymus repens, Calamagrostis epigeios, Solidago canadensis). G. perfoliata also grows in fissures of the sidewalks and pavements as in Loc-1. Due to its weedy character it is regularly mown but stands closer to the former LKM area are unmanaged. In 2008 the approximately three-hectare extent area was split from the former LKM industrial area to build the supermarkets.

Location-4: Miskolc-Újdiósgyőr: along the Pereces (or Erenyő) Brook at the DVTK football stadium; coordinates: $48^{\circ} 05^{\prime} 51,40^{\prime \prime} \mathrm{N}, 20^{\circ} 43^{\prime} 04,48^{\prime \prime} \mathrm{E}$; alt. $160 \mathrm{~m}$ a.s.I.; CEU grid: 7990.1. Observation: 23.8.2019 (AS, JK). Coenological data: relevé 14. (Tab. 2).

Approx. 60 individuals of $G$. perfoliata were detected at the new DVTK stadium area, along a 220-metre-long section of the bank of the canalised Pereces (or Erenyő) Brook. The ground surface is heavily modified, construction debris and slag were also used for stabilisation of the brook's bed. The former football stadium was demolished in 2016 and several new infrastructure elements emerged beside the new football arena (e.g. parking areas, pavements). The vegetation of the locality is species rich, dominated by tall herbs (such as Artemisia vulgaris, Tanacetum vulgare and Centaurea scabiosa ssp. spinulosa, the latter as a remnant of the original seminatural vegetation). The presence of $G$. perfoliata is restricted to more or less open surfaces. The intensive transformation of the area in the last years (with using debris materials, dumps, creation of new concrete infrastructure element) has facilitated also the naturalisation of annual pioneer weeds (e.g. Eragrostis pilosa, E. minor, Vulpia myuros, Panicum capillare, Crepis rhoeadifolia).

Location-5: Miskolc, along the Repülötér road (section of the road No. 306), north part of the town at the airport; coordinates: $48^{\circ} 07^{\prime} 49,92^{\prime \prime} \mathrm{N}, 20^{\circ} 47^{\prime} 29,46^{\prime \prime} \mathrm{E}$; alt. 118 $121 \mathrm{~m}$ a.s.I.; CEU grid: 7890.4. Observation: 24.8.2018 (AT), 23.8.2019 (AS, JK). Coenological data: relevé 15. (Tab. 2).

One individual of $G$. perfoliata was detected by A. Takács in 2018 at the Repülötér road on the margin of the asphalt road (at a traffic lamp). Later, in 2019 a longer section of the road was investigated and altogether 17 individuals in 7 subpopulations were counted. The plants occur in a 250-meter-long section of the road (Fig. 2/E). G. perfoliata occurs on the verge of the road, mostly in a mesophilous weedy community. The dominant accompanying species are Arrhenatherum elatius, Rubus caesius, Fragaria viridis and Glechoma hederacea. Some leguminous species are also characteristic and have a larger coverage, such as Lathyrus pratensis, Trifolium medium and Vicia cracca. The area is part of the Sajó (Slaná) River alluvium, 
so remnants of floodplain meadows are also noticeable (e.g. Sanguisorba officinalis, Dianthus collinus). Unfortunately, the typical invasive species of floodplains are also co-occurring here, such as Helianthus tuberosus, Solidago canadensis and Xanthium italicum. Thus, the typical salt-tolerant species flora on the verges are not yet developed, some pioneer weeds occur, such as Tragus racemosus, Eragrostis minor and Atriplex tatarica. A single specimen of Senecio inaequidens was also found in a crack of the road edge, which was in an early phase of naturalisation in the region (Süveges et al. 2020).

The main road No. 306 is the north-eastern bypass of Miskolc, which serves the purpose of diverting traffic from the city, coming from the M30 highway towards the main road No. 26. This infrastructure development took place in 2015 , but some sections of this road had been in use before as a local road.

Location-6: Sajókeresztúr, at the former Borsodi Ércelőkészítő Mű (hereinafter: BÉM) industrial park, east from the main road No. 26; coordinates: 48 09'30,62"N, 2046'29,03"E; alt. $125 \mathrm{~m}$ a.s.I.; CEU grid: 7890.2. Observation: 1.10.2019 (JK), 4.9.2020 (AS, JK). Coenological data: relevé 16-18. (Tab. 2).

Following a rapid survey of the site, approx. 400-500 individuals of G. perfoliata were detected in the yard of the former industrial area. The surface of the site is rather uneven, several smaller slag and chalk heaps can be observed with additional waste deposits (Fig. 2/F). The factory was built in 1969 in order to serve raw materials (iron ore, coke fuel, limestone) to nearby iron smelters (Miskolc - Diósgyőr and Ózd). It was regarded as the third biggest transshipment yard in Hungary, with its own railway lines. In the beginning of the 1990's, after the collapse of the iron production and technological changes the factory had modified its function of processing waste materials. After several problems with environmental regulations, the factory had closed in 2014. The yard of the former BÉM factory is currently abandoned, natural succession had started, but bare surfaces are still present at several spots. The G. perfoliata grows on heavily trampled anthroposol on flat areas or on the lower sections of the heap slopes and debris. The sparse vegetation is characterised by annual weeds (e.g. Artemisia artemisiifolia, Kochia scoparia, Eragrostis pilosa, Panicum capillare, Polygonum aviculare, Oenothera biennis), but several perennials, including invasive elements also occur (e.g. Calamagrostis epigeios, Sonchus oleraceus, Solidago canadensis, Helianthus tuberosus). In this locality salt-tolerant plants were also documented, including Puccinellia distans, Aster tripolium ssp. pannonicum, Spergularia maritima and Lotus tenuis at scattered patches among the ruderal stands.

We have also revisited the published occurrence at Gesztely in 2018 and 2020, but the population of Gypsophila perfoliata has not been detected again (the concerned CEU grid: 7891/4). We suppose that the species is extinct at this location, probably due to the landfill re-cultivation implemented in 2014. Bare surfaces were eliminated, and the site was covered with a soil blanket, and was sown with grasses 
(mostly Festuca spp.), which is currently managed by regular mowing. The present distribution of $G$. perfoliata in Hungary is shown on Fig. 3.

\section{2) Notes on habitat preference of Gypsophila perfoliata}

In its native range Gypsophila perfoliata grows on alkalic meadows or maritime habitats, but coenological data are rather sparse. In Ukraine, at the shores of the and Azov Seas it grows in plant communities with Ammophiletea (coastal mobile dune vegetation) and Cakiletea maritimae (pioneer plant communities of nitrophilous

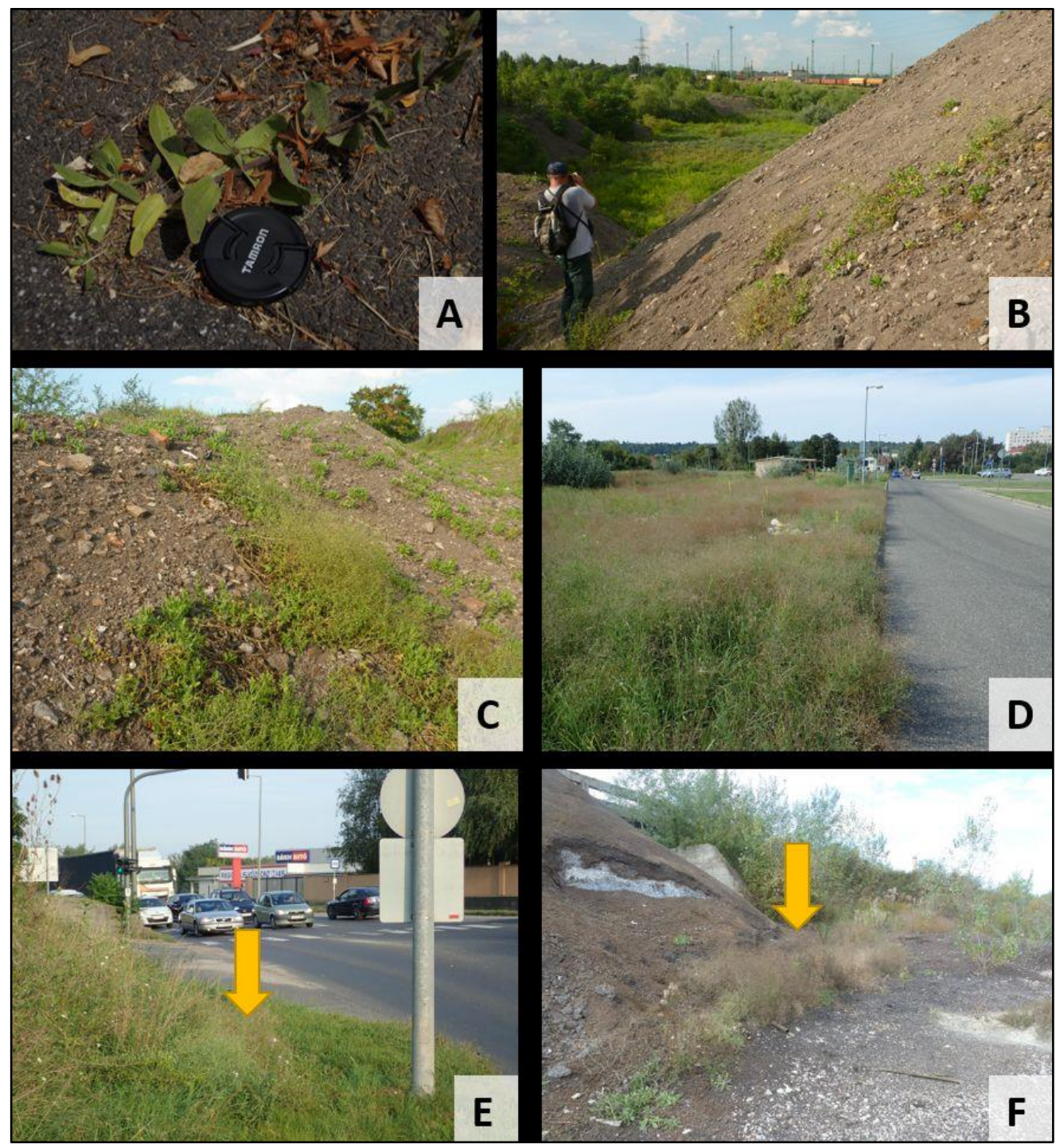

Fig. 2 Habitats of Gypsophila perfoliata in the studied area (A.: creeping stem of G. perfoliata in a crack of asphalt road at Loc-1.; B.-C.: G. perfoliata on the metalliferous slag heaps at Loc-2.; D.: G. perfoliata on parking area at Loc-3.; E.: occurrence of G. perfoliata on a road margin at Loc-5.; F.: G. perfoliata on abandoned factory yard at Loc-6. (Photo A - E: A. Schmotzer; F: J. Koscsó). 
annual herbs in strandlines of sandy and shingle beaches of the coasts) classes (Dubyna et al. 2020). The species is rather typical salt meadows in the steppe and forest-steppe zones (Festuco-Puccinellietea class) and was reported from Artemisio santonicae-Elytrigietum elongatae assotiations on solonetz or solonchak soils (Shishkin 1936; Dubyna \& Neuhäuslová 2000). The species is reported from the shoreline of the Black Sea in Romania, where it grows in different coastal and halophilic habitats with EU conservation importance according to the Habitats Directive (habitat codes: 1210, 2110, 2130, 2160; Făgăraş 2013). In mountainous areas, e.g. in the Zhetysu Alatau (Junggaria, Kazakhstan) G. perfoliata prefers slightly alkalic swamps and meadows in depressions of piedmont deserts (Dimeyeva et al. 2016). In China it occurs in forest grasslands, wet riversides on saline-alkaline soils and steppe sands, on altitudes between 500-1000 meters a.s.l. (Dequan \& Turland 2001). G. perfoliata (var. perfoliata) occurs in mining areas in Turkey, where it shows high resistance to boron levels, far exceeding the accepted toxic levels $\left(35 \mathrm{mg} \mathrm{kg}^{-1}\right)$ and flourishes in the zone of mines with the highest boron concentrations (Ozturk et al. 2010).

On its secondary adventive range $G$. perfoliata can be found in several ruderal vegetation communities, but in most cases, it occupies slightly alkalic secondary habitats (Sommerwerk et al. 2005). It was reported from associations of SpergularioPuccinellietum distantis (in potash heaps), characterized by high concentrations of different salts (sodium chloride, magnesium, calcium sulphate and carbonates). According to the literature data $G$. perfoliata occurs in more covered vegetation patches, belonging to Dauco-Melilotion community classes, resp. Rubus spp. Calamagrostis epigeios DC. ruderal communities (see also Tab. 1).

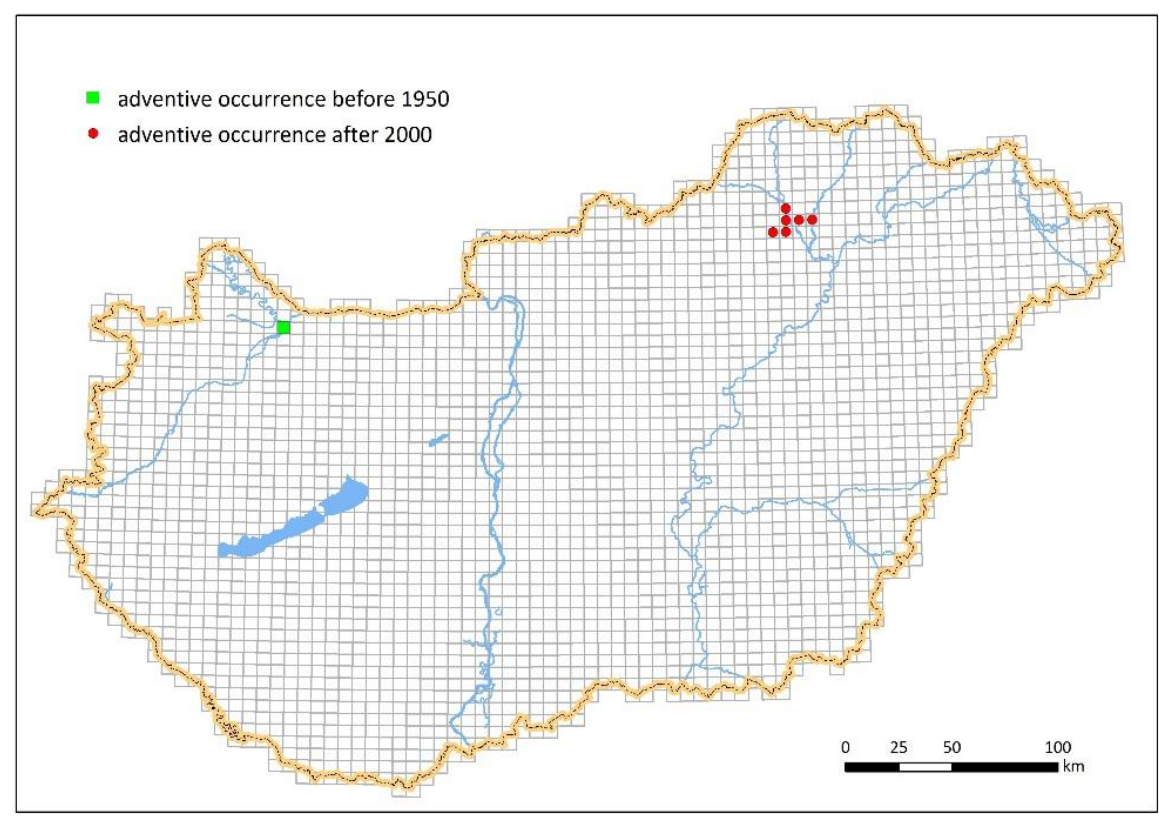

Fig. 3 The present distribution of Gypsophila perfoliata in Hungary. 
The floristic composition of Gypsophila perfoliata stands, documented in this study is based on 18 phytocoenological relevés and is summarised in Tab. 2 . The cover of the herb layer varies between 12 and 95\% (avr.: $46.4 \%$; SD \pm : 42.4). Overall, 76 vascular plants have occurred in the 18 assessed relevés. Species richness was remarkably variable, with the number of species per plot varying between 4 and 25 $(10.1 \pm 9.0)$. The number of species which occurred in only one relevés was high (43 species), with only 7 species registered to be present in more than 5 relevés: Conyza canadensis (frequency=10), Setaria pumila (9), Kochia scoparia (8), Solidago canadensis (8), Ambrosia artemisiifolia (7), Calamagrostis epigeios (7) and Micorrhinum minus (7). All documented locations had a pioneer character even if it occurred in industrial areas (yards, slag heaps) or along transport lines (side-walks and road verges). In all stands typical anthroposols could be found, where the surface was profoundly modified, removed or replaced. The bare ground admixed with metalliferous slag, waste and other materials was inhabited by stress-tolerant species, mostly annual weeds. Later, perennial plants might also be able to naturalise. Regular human impact at some sites can re-open the habitats, which can promote the repetition of secondary succession processes. The compliance of the stands with described plant associations is not evident, and the species can not be listed under any specific plant association. The most open stands, on warm slopes of the slag heaps are occupied by Salsolion ruthenicae Philippi 1971 or Eragrostion ciliansi-minoris Tüxen ex Oberdorfer 1954 alliances. The former group is reported mostly from secondary sandy areas on nutrient-poor soils, but a slight alkalisation is also mentioned (Chytrý 2009; Borhidi et al. 2012). The phenological and biomass production optimum of these communities are in (late) summer which period overlaps with the flowering time of $G$. perfoliata. In most cases $G$. perfoliata reaches significant coverage on the sites (the highest cover exceeded 50\%), being dominant in the occupied plot. Along road verges (see Loc-1 and Loc-5) G. perfoliata is more sporadic, its naturalisation success and population number depend on the specific characteristic of the site (e.g. presence of cracks, salinisation treatment method etc.). Under such circumstances $G$. perfoliata behaves mostly as a gap inhabitant. The secondary succession of these pioneer stands lead to a meso-xerophilous ruderal vegetation, alliances of Dauco-Melilotion Görs 1966 or ConvolvuloAgropyrion repentis Görs 1966. Nearby to documented G. perfoliata locations secondary scrub and tree encroachments were also observed, especially in abandoned areas, where pioneer woody plants, mostly invasive tree species were predominant (e.g. Ailanthus altissima, Robinia pseudoacacia, Celtis occidentalis). Alkalic habitat was only detected at Loc-6, which harboured typical alkalic meadow and sward elements, such as Puccinellia distans, Aster tripolium ssp. pannonicum and Spergularia maritima. The reason for the latter appearance of alkalic species in this site needs further investigation. 
Tab. 2 Floristic composition of Gypsophila perfoliata stands in the study area.

\begin{tabular}{|c|c|c|c|c|c|c|c|c|c|c|c|c|c|c|c|c|c|c|c|}
\hline Relevé number & 1 & 2 & 3 & 4 & 5 & 6 & 7 & 8 & 9 & $\begin{array}{l}1 \\
0\end{array}$ & $\begin{array}{l}1 \\
1\end{array}$ & $\begin{array}{l}1 \\
2\end{array}$ & $\begin{array}{l}1 \\
3\end{array}$ & $\begin{array}{l}1 \\
4\end{array}$ & $\begin{array}{l}1 \\
5\end{array}$ & $\begin{array}{l}1 \\
6\end{array}$ & $\begin{array}{l}1 \\
7\end{array}$ & $\begin{array}{l}1 \\
8\end{array}$ & Fr. \\
\hline Declination $\left({ }^{\circ}\right)$ & - & - & 5 & - & 5 & $\begin{array}{l}2 \\
0\end{array}$ & - & - & 5 & 5 & - & - & - & - & 5 & - & - & 5 & \\
\hline Exposition & - & - & $\mathrm{E}$ & - & $E$ & $\mathrm{~S}$ & - & - & $\mathrm{N}$ & $E$ & - & - & - & - & $\begin{array}{l}\mathrm{S} \\
\mathrm{E}\end{array}$ & - & - & $E$ & \\
\hline & 5 & 2 & 3 & 1 & 4 & 8 & 5 & 3 & 1 & 2 & 3 & 5 & 8 & 5 & 9 & 2 & 4 & 5 & \\
\hline Cover of herb layer & 9 & 1 & 9 & 7 & 2 & 8 & 3 & 2 & 2 & 4 & 0 & 2 & 4 & 8 & 5 & 5 & 3 & 9 & \\
\hline Species number per relevé & $\begin{array}{l}1 \\
0\end{array}$ & 5 & 9 & 4 & 7 & $\begin{array}{l}1 \\
2\end{array}$ & 7 & 6 & 9 & $\begin{array}{l}1 \\
0\end{array}$ & 9 & 8 & $\begin{array}{l}1 \\
1\end{array}$ & $\begin{array}{l}2 \\
5\end{array}$ & $\begin{array}{l}1 \\
2\end{array}$ & $\begin{array}{l}1 \\
3\end{array}$ & $\begin{array}{l}1 \\
7\end{array}$ & 8 & \\
\hline
\end{tabular}

$\mathrm{ChCl}$. Polygono arenastri-Poetea annuae species

Polygonum aviculare agg.

1

ChCl. Stellarietea mediae species

Conyza canadensis

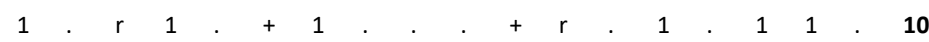

Setaria pumila

Panicum capillare

Chenopodium album agg.

Solanum nigrum

ChAll. Atricipion \& Sisymbrion species

Gypsophila perfoliata

Kochia scoparia

Ambrosia artemisiifolia

Microrrhinum minus

Salsola kali ssp. ruthenica

Digitaria sanguinalis

Lactuca serriola

$\begin{array}{lllllllllllllllllll}3 & 2 & 3 & 2 & 3 & 3 & 3 & 3 & 2 & 2 & 2 & 3 & 3 & 3 & 2 & 2 & 3 & 3 & 18\end{array}$

Medicago lupulina

ChAll. Eragrostion species

Eragrostis minor

$\mathrm{ChCl}$. Artemisietea vulgaris, incl. ChAll. Convolvulo-Agropyrion species

Lactuca saligna

1

Elymus repens

Convolvulus arvensis

Melica transsilvanica

$\mathrm{ChCl}$. Artemisietea vulgaris, incl. ChAll. Onopordion \& Dauco-Melilotion species

Oenothera biennis

Melilotus albus

Verbascum phlomoides

Melilotus officinalis

ChCl. Sedo-Scleranthetea species

Petrorhagia prolifera

Arenaria serpyllifolia

Indifferent species

Solidago canadensis

Calamagrostis epigeios 
Tab. 2 - cont

\begin{tabular}{|c|c|c|c|c|c|c|c|c|c|c|c|c|c|c|c|c|c|c|}
\hline Ailanthus altissima (juv.) & . & $\cdot$ & . & . & . & . & . & . & $\mathrm{r}$ & $\cdot$ & 1 & . & $r$ & . & . & $\cdot$ & . & . \\
\hline Erigeron annuus & . & ${ }^{\circ}$ & 1 & . & . & . & . & . & . & . & . & . & . & 1 & . & . & $\mathrm{r}$ & 3 \\
\hline Taraxacum sect. Ruderalia & 1 & . & . & . & . & . & . & . & . & $r$ & . & . & $r$ & . & . & . & . & . \\
\hline Cirsium vulgare & . & $\cdot$ & . & . & . & 1 & . & . & . & $\cdot$ & . & . & . & . & 1 & . & . & . \\
\hline Cynodon dactylon & . & . & 1 & . & . & ${ }^{\circ}$ & . & . & . & $\cdot$ & . & . & $\cdot$ & $r$ & . & . & . & . \\
\hline Plantago lanceolata & . & . & . & . & . & . & . & . & . & . & . & . & . & + & $r$ & . & . & . \\
\hline
\end{tabular}

Accompanying, accidental species with A-D value and number of the relevé (in brackets): Abutilon theoprasti 2 (6); Acer negundo (juv.) r (8); Apera spica-venti r (17); Arrhenatherum elatius 3 (15); Artemisia vulgaris r (14); Aster tripolium r (16); Atriplex patula r (13); Betula pendula (juv.) (9); Centaurea scabiosa ssp. spinulosa r (14); Cerastium vulgare 1 (1); Chenopodium strictum $r$ (14); Clinopodium vulgare r (14); Crepis pulchra $r$ (6); Diplotaxis tenuifolia $r$ (5); Echinochloa crus-galli $r$ (14); Echium vulgare r (17); Eragrostis pilosa r (8); Fallopia convolvulus 3 (6); Fragaria viridis 2 (15); Glechoma hederacea 1 (15); Lathyrus pratensis 1 (15); Lepidium ruderale $r(1)$; Linaria vulgaris $r(9)$; Lolium perenne $r(14)$; Lotus tenuis $r(16)$; Medicago $\times$ varia $r(14)$; Silene noctiflora $r(14)$; Mentha arvensis $+(14)$; Pimpinella saxifraga $r(14) ;$ Plantago major + (14); Poa annua $r(1) ;$ Poa compressa $r$ (17); P. pratensis agg. 2 (15); Populus alba (juv.) r (2); Portulaca oleracea 1 (1); Rubus caesius 2 (15); Sonchus oleraceus $r$ (16); Spergularia maritima r (16); Tanacetum vulgare 1 (14); Tragus racemosus $r$ (2); Trifolium medium 1 (15); T. repens 2 (14); Vicia cracca 15 (1).

Relevés: 1: Miskolc: Csorba-telep (Loc-1); 2-11: Miskolc: Gálos (Loc-2); 12-13: Miskolc: Kiss Ernő street (Loc-3); 14: Miskolc, Újdiósgyőr, DVTK stadium (Loc-4); 15: Miskolc, Repülőtér street (Loc-5); 16-18: Sajókeresztúr, BÉM industrial area (Loc-6).

\section{3) Naturalisation of Gypsophila perfoliata in the study area}

Gypsophila perfoliata occurs in ruderal habitats in Hungary, similarly to what has been reported from several central and eastern European countries across its adventive range (see Tab. 1). Its occurrence is restricted to anthropogenic habitats, heavily modified industrial and urban areas in the city of Miskolc and its surroundings. The closest adventive populations of this species are known from Slovakia and Poland, where the species was introduced unintentionally in the 19501960s: first record from Poland was documented in 1958 (Kuc 1958; Bartoszek \& Stachurska-Swakon 2016), while in Slovakia was reported for the first time in 1968 (Jehlík 1998; Eliáš \& Dítě 2012). Most regionally important steel factories (e.g. Kraków - Nowa Huta, Košice, Miskolc - Diósgyőr) imported the iron ore via ferroviatic transport from the former Soviet Union (from Krivoj Rog; now: Kryvyi Rih, Ukraine). It is important to highlight that the species in the Donetsk Basin also occurs as an adventive taxon, mostly occurring on slag heaps or on other industrially disturbed lands. In these technogenic ecotopes with phytotoxic environmental factors (increased insolation, amorphy, poor substrate, moisture deficit, etc.) the studied Gypsophila species rapidly forms stable and viable populations. Some experiments were also conducted to use these halophytes in phytorecultivation and phytoremediation of disturbed areas (Glukhov et al. 2014; Mazur et al. 2015). Several occurrences of $G$. perfoliata is known also from transshipment yards and along railways, which locations can serve as a possible source population for introduction 
to new regions. The population at Sajókeresztúr (Loc-6.) represents a stand that was introduced to a former transshipment yard, which had mutual connection with other industrial areas in the region (incl. LKM). Population sizes of G. perfoliata (esp. in Loc2 and Loc-4) are notably high, indicating a potentially older naturalisation of the species in these spots. In our opinion the species was introduced in the Miskolc region approximately at the same time as in the above mentioned Central European countries. The factory yards of the former LKM are inaccessible to the public, but according to aerial photos several massive slag heaps are still present in the area. The new supermarkets at Loc- 2 were built in an area which earlier belonged to the factory's yard. The flat surface for the development of the supermarkets was created by flattening the industrial waste materials. In these open ground surfaces, where the slag compartments are dominant, G. perfoliata thrives successfully. The steel factory and the exterior slag heaps are connected with industrial or public railway lines. The importance of railway lines in the spread of some plants is well known (Jehlík 1998; Májeková et al. 2014, 2020). All localities of the studied species (excluding Loc-1) are situated close to railway lines. With the decline of the steel production and associated environmental hazards the need for reusing industrial waste materials had emerged. Coal power plant soot, metallurgical and mining waste appeared to be suitable for the partial replacement of primary raw materials (gravel, stone) in road construction. The presence and spread of $G$. perfoliata along roads, at road verges might be explained by this phenomenon (esp. in the cases of Loc-1 and Loc-5). The utilisation of de-icing salt can also facilitate the spread of the subhalophyte $G$. perfoliata along roads. This phenomenon is well demonstrated in the expansion of maritime and continental salt-tolerant plants in Central Europe (Kocián 2016; Dítě \& Dítětová 2016; Schmidt et al. 2016; Fekete et al. 2018). The slag debris is also used at construction sites, mostly as ballast material. In the case of Loc1 the appearance of $G$. perfoliata could also be explained by the transposition of slag waste material to the site. The shopping area was constructed on the floodplain of the Sajó (Slaná) River, so a large amount of ballast material was needed for filling up the site, and the local metallurgic waste material was easily accessible for this purpose.

According to our findings, the alien status of $G$. perfoliata should be recategorized from 'casual' to the 'naturalised' stage (cf. Balogh et al. 2004). G. perfoliata reproduces consistently in our study area and sustains viable populations over many life cycles without the direct intervention of humans. These observations might reflect the further expansion potential of the species, especially in industrial and urban areas. Building on our present knowledge we presume the existence of additional locations in Hungary where the species might occur, and which are currently overlooked by botanists. All former or active steel plants should be investigated with special attention to slag heaps, or transshipment yards (e.g. Ózd, Borsodnádasd, Dunaújváros, Záhony). As a halophyte species its occurrence can also be expected along newly constructed roads or other linear anthropogenic elements. Management measures and risk analysis targeting $G$. perfoliata should be 
implemented in the near future, but this issue cannot be handled separately from the necessary waste management tasks.

\section{Acknowledgement}

The comments of the anonymous reviewers helped to improve the quality of our paper. The authors are grateful to Lajos Somlyay (Budapest) for providing literature and for Csaba Fitala (Eger) for the translation of papers written in Russian. We would like to thank Orsolya Vincze (Debrecen), who kindly improved the English of the submitted version. This research was partly supported by the Hungarian Research Fund (NKFI-OTKA K132573).

\section{References}

Allen D., Bilz M., Leaman D. J., Miller R. M., Timoshyna A. \& Window J. (2014): European Red List of Medicinal Plants. - Publications Office of the European Union, Luxembourg. 61 pp.

Amarell U. (2002): Fundorte bemerkenswerter Arten aus Sachsen-Anhalt. - Mitt. florist. Kart. Sachsen-Anhalt 7: 31-34.

Amini E., Zarre S. \& Assadi M. (2011): Seed micro-morphology and its systematic significance in Gypsophila (Caryophyllaceae) and allied genera. - Nordic J. Bot. 29: 660-669. doi.org/10.1111/j.1756-1051.2011.01208.x

Angelo R. \& Boufford D. E. (2011): Atlas of the Flora of New England: Caryophyllidae. Rhodora 113(956): 419-513. doi.org/10.3119/0035-4902-113.956.419

Ataşlar E., Erkara I. P. \& Tokur S. (2009): Pollen morphology of some Gypsophila L. (Caryophyllaceae) species and its taxonomic value. - Turkish J. Bot. 33(5): 335-351. DOI: 10.3906/bot-0810-19

Balabanova V., Zdraveva P., Kožuharova E., Krasteva I. \& Nikolov S. (2009): A possibility for cultivation and phytochemical study of endangered Gypsophila trichotoma Wend. Comptes rendus de l'Académie bulgare des Sciences 62(10): 1247-1252.

Balogh L., Dancza I. \& Király G. (2004): A magyarországi neofitonok időszerű jegyzéke és besorolásuk inváziós szempontból. (Actual list of neophytes in Hungary and their classification according to their success). - In: Mihály B. \& Botta-Dukát Z. (Eds.). Biológiai inváziók Magyarországon. Özönnövények. (Biological invasions in Hungary. Invasive plants.) p. 61-92. - TermészetBúVÁR Kiadó, Budapest.

Bardkoudah Y. I. (1962): A revision of Gypsophila, Bolanthus, Ankyropetalum and Phryna. Wentia 9: 1-203. doi.org/10.1111/j.1438-8677.1962.tb00012.x

Barkworth M. E., Capels K. M. \& Long S. (Eds.) (1993): Flora of North America, North of Mexico. Vol. 5. Magnoliophyta: Caryophyllidae, Part 2. - Oxford University Press, New York-Oxford. 656 pp.

Bartoszek W. \& Stachurska-Swakoń A. (2016): Gypsophila perfoliata (Caryophyllaceae) in Poland. - Polish Bot. J. 61(2): 257-262. doi.org/10.1515/pbj-2016-0030

Bittrich V. (1993): Caryophyllaceae. - In: Kubitzki K., Rohwer J. \&. Bittrich V. (Eds.). The families and genera of vascular plants. Vol. 2. Magnoliid, Hamamelid, and Caryophyllid families, p. 206-236. - Springer Verlag, Berlin.

Bochkin V. D. \& Vinogradova Y. K (2016): Flora of the railways in Moscow city. - Vestnik Permskogo universiteta. Ser.: Biologiya 2: 89-95. [in Russian]

Borhidi A., Kevey B. \& Lendvai G. (2012): Plant communities of Hungary. - Akadémiai Kiadó, Budapest. 544 pp. 
Buttler K. P. \& Hand R. (2008): Liste der Gefäßpflanzen Deutschlands. - Kochia, Beiheft 1: 1107.

Chytrý M. (Ed.) (2009): Vegetace České republiky Vol. 2: Ruderální, plevelová, skalní a sutová vegetace. (Vegetation of Czech Republic. Vol. 2: Ruderal, weed, rock and scree vegetation). - Academia, Praha. 520 pp.

Ciocârlan V. (2011): Vascular flora of the Danube Delta. - Analele Stiintifice ale Universitatii „Al. I. Cuza" din lasi 57(1): 41-64.

Csorba P. (Ed.) (2018): X. Landscapes. - In: Kocsis K. (Ed.). National Atlas of Hungary: Natural environment. Vol. 1. p. 112-129. - Hungarian Academy of Sciences, Research Centre for Astronomy and Earth Sciences, Geographical Institute, Budapest.

Dequan L. \& Turland N. J. (2001): Gypsophila L. - In: Wu Z. Y., Raven P. H. \& Hong D. Y. (Eds.). Flora of China. Vol. 6. Caryophyllaceae through Lardizabalaceae. p. 108-113. - Science Press, Beijing, and Missouri Botanical Garden Press, St. Louis.

Dihoru G. \& Negrean G. (2009): Cartea roşie a plantelor vasculare din România. (Red book of vascular plants of Romania.) - Editura Academiei Române, Bucureşti. 630 pp.

Dimeyeva L. A., Sitpayeva G. T., Ussen K., Orlovsky L., Ablaikhanov E., Islamgulova A. F., Zhang Y. \& Suleimenova N. S. (2016): Meadow vegetation of the Zhetysu Alatau mountains. Appl. Ecol. Environ. Res. 14: 375-398. doi.org/10.15666/aeer/1404_375398

Dítě D. \& Dítětová Z. (2016): Halophytes spreading along roadsides of northern Slovakia. Thaiszia - J. Bot. 26(2): 165-172.

Doroftei M., Oprea A., Ștefan N. \& Sârbu I. (2011): Vascular wild flora of Danube Delta Biosphere Reserve. - Scientific Annals of the "Danube Delta" Institute (Tulcea) 17: 15-52.

Dövényi Z. (Ed.) (2010): Magyarország kistájainak katasztere (Cadastre of landscape microregion of Hungary). Vol. 1. - MTA Földtudományi Kutatóintézet, Budapest. 430 pp.

Dvirna T. S. (2017): Alien plant species (ephemerophytes) in Romensko-Poltavsky Geobotanical District, Ukraine. - Environ. Socio-econom. Stud. 5(3): 23-30. doi.org/10.1515/environ-2017-0013

Dzhus M. A. (2016): Gypsophila paulii Klokov (Caryophyllaceae, Caryophylloideae) - a new alien species for Belarusian flora. - Vestnik BGU. Ser. 2. Khimiya. Biol. Geogr. 2: 1-4. [in Russian]

Dubyna D. V., Dziuba T. P., lemelianova S. M. \& Makhynia L. M. (2020): Syntaxonomy and ecological differentiation of the pioneer vegetation of Ukraine. 1. Classes: Cakiletea maritimae, Ammophiletea, Crithmo-Staticetea, Crypsietea aculeatae, Therosalicornietea. - Biosyst. Divers. 28(1): 68-80. doi.org/10.15421/012011

Dubyna D. V. \& Neuhäuslová Z. (2000): Salt meadows (Festuco-Puccinellietea) of the Biryuchij Island Spit in the Azov Sea, Ukraine. - Preslia 72: 31-48.

Eliáš jun P. \& Dítě D. (2012): 27. Gypsophila L. - Gypsomilka. - In: Goliašová K. \& Michalková E. (Eds.). Flóra Slovenska. Vol. VI/3. p. 551-569. - VEDA, Bratislava.

Evarts-Bunders P., Evarte-Bundere G., Romancevica N., Brutane K., Novicka I. \& Nitcis M. (2012): Rare anthropophytes in the flora of Daugavpils City [Latvia]. - Latvijas Veg. 22: 2943.

Făgăraş M. (2013): Habitats with conservation significance and psammophilous plant associations from Sulina beach (Danube Delta Biosphere Reserve). - Analele Ştiinţifice ale Universităţii „Al. I. Cuza” din laşi 59(2): 85-98.

Făgăraş M., Anastasiu P. \& Gavril N. (2010): Rare and threatened plants in the Black Sea coastal area between Cape Midia (Romania) and Cape Kaliakra (Bulgaria). - Bot. Serbica 34(1): 37-43. 
Fekete R., Mesterházy A., Valkó O. \& Molnár V. A. (2018): A hitchhiker from the beach: the spread of the maritime halophyte Cochlearia danica along salted continental roads. Preslia 90: 23-37. doi.org/10.23855/preslia.2018.023

Galasso G., Conti F., Peruzzi L., Ardenghi N. M. G., Banfi E., Celesti-Grapow L., et al. \& Bandini Mazzanti M. (2018): An updated checklist of the vascular flora alien to Italy. - PI. Biosystems 152(3): 556-592. doi.org/10.1080/11263504.2018.1441197

Garve E. (1999a): Zur Flora der Kalihalden in der Region um Hannover. - Ber. Naturhistorischen Ges Hannover 141: 197-218.

Garve E. (1999b): Neu aufgetretene Blütenpflanzen an salzhaltigen Rückstandshalden in Niedersachsen. - Braunschweiger Geobot. Arbeiten 6: 171-191.

Garve E. \& Garve V. (2000): Halophyten an Kalihalden in Deutschland und Frankreich (Elsass). - Tuexenia 20: 375-417.

Ghendov V., Izverscaia T. \& Şabanova G. (2012): Pre-identified Red List of vascular plants in the flora of Republic of Moldova. - Buletin Ştiinţific. Revista de Etnografie, Ştiinţele Naturii şi Muzeologie (Serie Nouă) 29(16): 12-14.

Glazunov V. A., Nikolaenko S. A. \& Filippov I. V. (2016): Floristic findings in west Siberia. - Bot. Zhurnal 101(9): 1075-1082. [in Russian] doi.org/10.1134/s0006813616090064

Glukhov O. Z., Kharkhota G. I., Prokhorova S .I. \& Agurova I. V. (2014): Adaptive strategies of the halophyte populations. - Annali di Botanica 4: 115-124. doi.org/10.4462/annbotrm10268

Guder Ch., Evers Ch. \& Brandes D. (1998): Kalihalden als Modellobjekte der kleinräumigen Florendynamik dargestellt an Untersuchungen im nördlichen Harzvorland. - Braunschw. Naturkundl. Schr. 5: 641-665.

Gutte P. \& Klotz S. (1985): Zur Soziologie einiger urbaner Neophyten. - Hercynia-Ökologie und Umwelt in Mitteleuropa 22(1): 25-36.

Jäger E. J. \& Werner K. (2005): Rothmaler: Exkursionsflora von Deutschland. Band 4. Gefäßpflanzen. Kritischer Band. 10. Auflage. - Spektrum Akademischer Verlag, Heidelberg. $980 \mathrm{pp}$.

Jalas J. (1955): Hemerobe und hemerochore Pflanzenarten. Ein terminologischer Reformversuch. - Acta Soc. Fauna Flora Fenn. 72: 1-15.

Jalas J. \& Suominen J. (Eds.) (1986): Atlas Florae Europaeae. Distribution of Vascular Plants in Europe. Vol. 7. Caryophyllaceae (Silenoideae). - The Committee for Mapping the Flora of Europe et Societas Biologica Fennica Vanamo, Helsinki. 229 pp.

Jehlík V. (Ed.) (1998): Cizí expanzivní plevele České republiky a Slovenské republiky. (Alien expansive weeds of the Czech Republic and the Slovak Republic). - Academia, Praha. 506 pp.

Jehlík V. \& Dostálek J. (2008): Influence of railway transport in the south-east of Slovakia on formation of adventive flora in Central Europe. - Biodiv. Res. Conserv. 11-12: 27-32.

Jehlík V., Zaliberová M. \& Májeková J. (2017): The influence of the Eastern migration route on the Slovak flora - a comparison after 40 years. - Tuexenia 37: 313-332. doi.org/10.14471/2016.37.023

Kaplan Z., Danihelka J., Šumberová K., Chrtek J. Jr., Rotreklová O., Ekrt L., Štěpánková J., Taraška V., Trávníček B., Prančl J., Ducháček M., Hroneš M., Kobrlová L., Horák D. \& Wild J. (2017): Distributions of vascular plants in the Czech Republic. Part 5. - Preslia 89: 333439. doi.org/10.23855/preslia.2017.333

Király G. (2003): A magyarországi flóratérképezés módszertani alapjai. Útmutató és magyarázat a hálótérképezési adatlapok használatához. - Flora Pannonica 1(1): 3-20. 
Király G. (Ed.) (2009): Új magyar füvészkönyv. Magyarország hajtásos növényei. Határozókulcsok. (New Hungarian Herbal. The vascular plants of Hungary). - Aggteleki Nemzeti Park Igazgatóság, Jósvafő. 616 pp.

Király G., Molnár Zs., Bölöni J., Csiky J. \& Vojtkó A. (Eds.) (2008): Magyarország földrajzi kistájainak növényzete. (Vegetation of Hungarian landscape microregions). - MTA ÖBKI, Vácrátót. 248 pp.

Kocián P., Danihelka J., Lengyel A., Chrtek J. Jun., Ducháček M. \& Kúr P. (2016): Limonka Gmelinova (Limonium gmelinii) na dálnicích České republiky. (Limonium gmelinii on highways in the Czech Republic.) - Acta Rer. Natur. 19: 1-6.

Korkmaz M. \& Özçelik H. (2011): Economic importance of Gypsophila L., Ankyropetalum Fenzl and Saponaria L. (Caryophyllaceae) taxa of Turkey. - African J. Biotech. 10(47): 95339541. doi.org/10.5897/AJB10.2500

Kornaś J. (1990): Plant invasions in Central Europe: historical and ecological aspects. - In: di Castri F., Hansen A. J. \& Debussche M. (Eds.). Biological Invasions in Europe and the Mediterranean Basin. Monographiae Biologicae. Vol 65. p. 19-36. - Springer, Dordrecht. doi.org/10.1007/978-94-009-1876-4_2

Kuc M. (1958): Gypsophila trichotoma Wend. w środkowej Europie. (Gypsophila trichotoma Wend. in Central Poland.) - Fragm. Florist. Geobot. 3(2): 9-35.

López González G. (1990): 31. Gypsophila L. - In: Castroviejo S. (Ed.). Flora Iberica. Plantas vasculares de la Peninsula Ibericas e Islas Baleares. Vol. 2. Platanaceae - Plumbaginaceae (Partim), p. 408-415. - Real Jardín Botánico, C.S.I.C. Madrid.

Mabberley D. J. (2008): Mabberley's plant-book: a portable dictionary of plants, their classifications, and uses. - Cambridge University Press, Cambridge. 1021 pp.

Mahn D. (1997): Fundmeldungen. Neufunde - Bestätigungen - Verluste. - Bot. Naturschutz Hessen 9: 171.

Marhold K. (2011+): Caryophyllaceae. - In: Euro+Med Plantbase - the information resource for Euro-Mediterranean plant diversity.

http://www.europlusmed.org/cdm_dataportal/taxon/f1bead72-d686-4d5e-968778ac1682835a [Accessed on 30.12.2020].

Mazur A. Y., Kucherevskyi V. V., Shol H. N., Baranets M. O., Sirenko T. V. \& Krasnoshtan O. V. (2015): Biotechnology for iron ore dump remediation by creating steady plants associations. - Science and Innovation 11(4): 37-46. doi.org/10.15407/scine11.04.037

Májeková J., Letz D. R., Slezák M., Zaliberová M. \& Hrivnák R. (2014): Rare and threatened vascular plants of the railways in Slovakia. - Biodivers. Res. Conserv. 35(1): 75-85. doi.org/10.2478/biorc-2014-0024

Májeková J., Zaliberová M., Andrik E. J., Protopopova V. V., Shevera M. V. \& Ikhardt P. (2020): A comparison of the flora of the Chop (Ukraine) and Čierna nad Tisou (Slovakia) border railway stations. - Biologia (2020): 1-21. doi.org/10.2478/s11756-020-00592-x

Medvecká J., Kliment J., Májeková J., Halada L., Zaliberová M., Gojdičová E., Feráková V. \& Jarolímek I. (2012): Inventory of the alien flora of Slovakia. - Preslia 84(2): 257-309.

Minarchenko V. M. (2017): Threatened medicinal plants of Ukraine: an assessment of the current protection status. - J. Plant Dev. 24: 117-131.

Mohlenbrock R. H. \& Ladd D. M. (1978): Distribution of Illinois Vascular Plants. Ed. 1. Southern Illinois University Press, Carbondale and Edwardsville. 296 pp.

Molnár Cs. (2014): Florisztikai adatok a Harangod és a Dél-Cserehát löszvidékéről. (Floristical data from loess substrate of Harangod and South-Cserehát (NE Hungary)). - Kitaibelia 19(1): 105-113. 
Molnár Cs., Csathó A. I., Molnár Á. P. \& Pifkó D. (2019): Amendments to the alien flora of the Republic of Moldova. - Stud. Bot. Hung. 50: 225-240. doi.org/10.17110/StudBot.2019.50.1.225

Mosyakin S. L. \& Yavorska O. G. (2002): The nonnative flora of the Kiev (Kyiv) urban area, Ukraine: a checklist and brief analysis. - Urban habitats 1(1): 45-65.

Nikitin N. A. (2017): Structure and dynamics of alien flora of the railroads in the forest-steppe zone of Middle Volga Region. - Samara J. Sci. 6(3):20-24.

Niklfeld H. (1971): Bericht über die Kartierung der Flora Mitteleuropas. - Taxon 20(4): 545571. doi.org/10.2307/1218258

Nótári K., Nagy T., Löki V., Ljubka T., Molnár V. A. \& Takács A. (2017): Az ELTE füvészkert herbáriuma (BPU). (The herbarium of the Botanical Garden of Eötvös Loránd University (BPU)) - Kitaibelia 22(1): 55-59. doi.org/10.17542/kit.22.55

Oberdorfer E. (2001): Pflanzensoziologische Exkursionsflora für Deutschland und angrenzende Gebiete. - 8. Edition. Verlag Eugen Ulmer, Stuttgart. 1056 pp.

Oprea A. \& Sîrbu C. (2010): Sisymbrium volgense (Brassicaceae) in the flora of Romania. Analele Universităţii din Oradea, Fascicula Biologie 17(2): 296-299.

Oprea A., Barina Z. \& Sîrbu C. (2012): Euphorbia davidii Subils (Euphorbiaceae) - an alien species new to the Romanian flora. - Contr. Bot. Univ. Babes-Bolyai Cluj-Napoca 47: 712.

Ozturk M., Sakcali S., Gucel S. \& Tombuloglu H. (2010): Boron and Plants. - In: Ashraf M., Ozturk M. \& Ahmad M. (Eds.). Plant Adaptation and Phytoremediation, pp. 275-311. Springer, Dordrecht. doi.org/10.1007/978-90-481-9370-7_13

Pál V. (2017): Technology and the environment in state-socialist Hungary. An economic history. - Springer Verlag. 263 pp. doi.org/10.1007/978-3-319-63832-4

Pavlenko A. O., Krasova O. O. \& Korshykov I. I. (2017): Syngenesis processes on iron ore dumps in the northern part of Kryvyi Rih area. - Ukr. Bot. J. 74(4): 360-372. doi.org/10.15407/ukrbotj74.04.360

Petrova A. \& Vladimorov V. (Eds.) (2009): Red List of Bulgarian vascular plants. - Phytol. Balcan. 15(1): 63-94.

Petrova A. (2011): Gypsophila trichotoma. - In: Peev D. \& Vladimirov V. (Eds.). Red Data Book of the Republic of Bulgaria. Vol. 1 - Plants and Fungi. Institute of Biodiversity and Ecosystem Research - BAS. Digital Edition. http://eecodb.bas.bg/rdb/en/vol1/index.html [Accessed on 30.12.2020].

Pînzaru P., Chiriac E., Nedbaliuc B. \& Aluchi N. (2018): Contribuții la studiul plantelor rare din bariera Sculeni (Chișinău). - In: Duca M. \& Potîng T. (Eds.). Biodiversitatea în contextul schimbărilor climatice. Vol. 2. p. 79-82. - Universitatea de Stat "Dimitrie Cantemir", Chișinău.

Pismarkina E. V. \& Silaeva T. B. (2018): Naturalization features of alien plants in the northwest of the Volga Upland. - Russ. J. Biol. Invasions 9(2): 163-174.

Pliszko A. (2016): New records of Gypsophila perfoliata (Caryophyllaceae) in Poland. - Acta Mus. Siles. Sci. Nat. 65: 215-218. doi.org/10.1515/cszma-2016-0025

Polgár S. (1926): Neue Beiträge zur Adventivflora von Győr (Westungarn) III. - Magyar Bot. Lapok 24: 15-23.

Polgár S. (1941): Győrmegye flórája. (Flora Comitatus Jaurinensis.) - Bot. Közlem. 38(5-6): 201-352.

Priszter Sz. (1985): A magyar flóra és vegetáció rendszertani-növényföldrajzi kézikönyve 7. (Synopsis systematico-geobotanica florae vegetationisque Hungariae. Vol. 7). Akadémiai Kiadó, Budapest. 683 pp. 
Pyšek P., Lambdon P. W., Arianoutsou M., Kühn I., Pino J., \& Winter M. (2009): Alien vascular plants of Europe. - In: DAISE Handbook of alien species in Europe. p. 43-61. - Springer, Dordrecht. doi.org/10.1007/978-1-4020-8280-1_4

Rauschert S. (1977): Die in der DDR eingebürgerten ausdauernden Gypsophila-Arten. - Mitt. florist. Kart. Sachsen-Anhalt 3(2): 14-33.

Schmidt D. (2016): Polgár Sándor és az adventívflóra kutatása. (Sándor Polgár and the research of the adventive flora of Hungary.) - Kitaibelia 21(2): 188-197. doi.org/10.17542/kit.21.188

Schmidt D., Dítětová Z., Horváth A. \& Szűcs P. (2016): Coastal newcomer on motorways: the invasion of Plantago coronopus in Hungary. - Stud. Bot. Hung. 47: 319334.doi.org/10.17110/StudBot.2016.47.2.319

Schnedler W. (1977): Pflanzen, von denen in der mitteleuropäischen Literatur selten oder gar keine Abbildungen zu finden sind: Folge II. Gypsophila perfoliata, scorzonerifolia, tomentosa. - Gottinger Floristische Rundbriefe 11: 21-26.

Seregin A. P. (2003): Some new and rare species of Vladimir Province flora. - Byull. Mosk. Ova Ispyt. Prir., Otd. Biol. 108(6): 61-63. [in Russian]

Shishkin B. K. (Ed.) (1936): Gyspohila L. - In: Komarov V. L. (Ed.). Flora of the U.S.S.R. Vol. 6. p. 738-770. - Izdatel'stvo Akademii Nauk SSSR, Moskva-Leningrad. [in Russian]

Simon G., Márta K. \& Barakonyi-Tóth V. (2017): Mérgezett örökségünk. Szennyezett területek, időzített vegyi bombák Magyarországon. (Our poisoned heritage. Contaminated areas, delayed-action chemical bombs in Hungary.) - Greenpeace Hungary, Budapest. 73 pp.

Simon T. (2000): A magyarországi edényes flóra határozója. Harasztok - Virágos növények. (Identification keys to the Hungarian vascular flora. Ferns - Flowering plants.) - Nemzeti Tankönyvkiadó, Budapest. 846 pp.

Somlyay L. (2009): Alien Gypsophila taxa in the flora of Hungary. - Stud. Bot. Hung. 40: 173180.

Sommerwerk A., Partzsch M., Wesche K. \& Hensen I. (2005): Site conditions and association of the two adventive species Gypsophila perfoliata and $G$. scorzonerifolia (Caryophyllaceae) in central Germany. - Hercynia 38: 263-286.

Süveges K., Takács A., Nagy T., Schmotzer A. \& Koscsó J. (2020): Florisztikai adatok a Tiszántúl északi pereméről II.: Borsodi-ártér és Sajó-Hernád-sík (Floristic data from the northern edge of the floristic region 'Crisicum' (NE Hungary) II.) - Kitaibelia 25(2): 169-186. doi.org/10.17542/kit.25.169

Święs F. \& Wrzesień M. (2002): Rare vascular plants of the railway areas in Central-Eastern Poland. I. Lublin Upland, eastern part, Roztocze, Volhynia Upland. - Ann. Univ. Mariae Curie-Sklodowska, Sect. C, Biol. 57: 1-23.

Takács A., Schmotzer A. \& Sulyok J. (2013): Florisztikai adatok a Sajó-Hernád-sík területéről (Floristical data from the Sajó-Hernád Plain (NE-Hungary).) - Kitaibelia 18(1-2): 73-88.

Tremp H. (2005): Aufnahme und Analyse vegetationsökologischer Daten. - Verlag Eugene Ulmer, Stuttgart. $141 \mathrm{pp}$.

Tretiyakov D. I. (1988): The new adventive plant species in the Byelorussian flora. - Bot. Zhurn. 73(6): 903-910. [in Russian]

Valcheva M., Sopotlieva D. \& Apostolova I. (2020): Current state and historical notes on sand dune flora of the Bulgarian Black Sea Coast. - Flora 267: 1-18. doi.org/10.1016/j.flora.2020.151594

Valev S. (1966): Gypsophila L. - In: Jordanov D. (Ed.). Flora Republicae Popularis Bulgaricae. Vol. 3. p. 388. - Aedibus Academiae Scientiarum Bulgaricae, Sofia. 
Vasjukov V. M. \& Novikova L. A. (2017): Naturalized alien plants in Penza Region. - Samara J. Sci. 6(1): 19-22. doi.org/10.17816/snv201761103 [in Russian]

Vinogradova Y. K., Bochkin V. D., Mayorov S. R., Teplov K. \& Barinov A. V. (2017): Historical flora of Moscow's Railway Junction (until 2012). - Hortus Botanicus 12: 77106.doi.org/10.15393/j4.art.2017.3402 [in Russian]

Vladimirov V. \& Petrova A. S. (2012): Grindelia squarrosa: a new alien species for the Bulgarian flora. - Phytol. Balcan. 18(3): 315-318.

Williams E. V., Breidy J., van Slageren M. \& Khairallah S. (2015): New records for the flora of Lebanon. - Webbia 70(2): 323-327. doi.org/10.1080/00837792.2015.1070490

Yeremenko N. S. (2019): Syngenetic changes of ruderal vegetation in Kryvyi Rih city. - Ukr. Bot. J. 76(1): 31-41. doi.org/10.15407/ukrbotj76.01.031 [in Ukrainian].

Received: February $2^{\text {nd }} 2021$

Revised: March 22 2021

Accepted: April gth $^{\text {th }} 2021$ 